be taken as the best expression of an attempt to save the beauty of the Kentish countryside in face of a possible industrial development. In the valley below Aylesham Wood, Nature offers a site for a town of ten thousand inhabitants which gives the planner of towns, both in the form and the setting of the valley; his maximum opportunity. The collieries, though less than a mile away, are effectively hidden by rising ground, the summit of which, crowned by woods and spinneys, forms an effective horizon. This Aylesham scheme is a striking application of geographical science to the economic and social needs of our times. It is one in which the unconscious and empirical adjustment due to slow growth and lack of policyillustrated by Mrs. Ormsby's regional survey of London-may be replaced by a sound but not too rigid plan of organised urban development.

\section{The Proposed New Biological Station in Bermuda.}

WE have recently received from Prof. Herbert W. Rand, of Harvard University, a statement setting forth the history of the Bermuda Biological Station and the steps which are being taken for its reorganisation with the view of placing it on a permanent foundation and of extending its usefulness.

The station was inaugurated in 1903 through the joint activities of Profs. C. L. Bristol (New York) and E. L. Mark (Harvard), and since that time about 250 workers have carried out investigations at the station, and 141 published papers have been issued.

In August 1925 a group of American biologists interested in the Bermuda Station met to consider its future, and proposed a scheme for its complete reorganisation on the same general lines as those which have proved so successful in the case of Wood's Hole. The first step was to communicate with biologists who had either worked in Bermuda or for other reasons might be expected to be interested in the work of the station, and replies from about 150 were received, and these biologists form the corporation. They were asked to nominate a committee of reorganisation, which met in New York in Nov. 1925. Recognising the importance of securing the co-operation and support of the Bermudians, this committee sent letters to the Governor of Bermuda, to former members of the Bermuda Natural History Society, and to several other residents of the island. The responses are stated to be most encouraging. The committee arranged for the election, by ballot of the members of the corporation, of a board of twelve trustees, and it was provided that four of these should be non-residents of the United States. These are Dr. E. J. Allen, Plymouth; Prof. J. H. Ashworth, Edinburgh; Dr. A. G. Huntsman, Director of the Atlantic Experimental Station for Fisheries, Halifax, Canada; and Dr. E. A. MeCallan, Director of Agriculture, Bermuda. The American trustees are Prof. E. G. Conklin, Dr. E. V. Cowdry, Dr. C. B. Davenport, Profs. B. M. Duggar, R. A. Harper, R. G. Harrison, E. L. Mark, and H. W. Rand.

Papers of incorporation under the laws of the State of New York have been prepared and approved, so that the station is authorised to accept and hold funds to establish and maintain a station for scientific study in biology. A committee is investigating the possible sites for the new station and is drawing up the detailed plans for the station and its equipment.

It is hoped that the government of Bermuda may be willing to make some provision for the station, possibly in connexion with the new aquarium now in course of construction. The Royal Society of London has intimated its interest in the scheme to widen the scope and value of a station offering such exceptional advantages of position, which, though situated in British territory, has hitherto owed its existence and development to American enterprise, and the National Research Council at Washington has passed a vote approving the project.

We understand that, when the organisation is completed, there is every hope that funds to a substantial amount will be forthcoming from America to put the station upon a sound financial basis and to make it a first-class laboratory with thoroughly adequate equipment. British marine biologists will, we are sure, follow with sympathetic interest the efforts of the committee to this end. The advantages of the Bermudas for biological research are considerable; the semi tropical fauna can be studied under reasonable conditions of living and of climate through. out the year, and the station will be readily accessible, being reached in about forty-eight hours from New York. A well-equipped station in the Bermudas will afford the opportunity for the proper investigation of the semi-tropical waters of the Atlantic, and in these studies it is hoped British and American scientific men will be associated. We cordially wish the committee success in its endeavours to provide the means for the furtherance of this important work in marine biology.

\section{University and Educational Intelligence.}

Cambridge.-A. R. Clapham, Downing College, has been appointed to the Frank Smart University studentship in botany.

Dr. George McOwan, lecturer in chemistry in the United College of St. Salvator and St. Leonard, University of St. Andrews, has been appointed reader in chemistry at Raffles College, Singapore.

A Report on Higher Degrees has been issued by the Association of University Teachers as a supplement to the University Bulletin, vol. 6, No. 1. It represents the results of the labours of a committee of the Association appointed to inquire into the conditions under which higher degrees are awarded in the universities of Great Britain. Several years ago a similar inquiry was undertaken by the Universities Bureau of the British Empire, and summaries of the conditions have since been published in the "Universities Year-book." The committee of the A.U.T., however, has not rested content with recording existing conditions, but has fitted its record into a convenient tabular form, and has gone so far as to formulate general principles and even to suggest standard regulations which it commends to the careful consideration of the universities on the ground that, if some common agreement could be achieved, it would be to the great advantage of university study and research. The general principles recommended are: that the D.Litt. and D.Se. should imply conspicuous ability and originality and distinguished and sustained achievement; the Ph.D., ability to study a problem systematically and to relate results to the general body of knowledge of the subject, and a definite contribution to knowledge or scholarship; and the degree of Master, the mastery of the technique of investigation. The suggested regulations include a viva voce examination for the Ph.D. and for the Master's degree. Standardisation is not a word to conjure with in university circles, but this report seems to deserve the consideration it asks for. 